This is the accepted version of Turner, Lewis (2015) 'Explaining the (non-)encampment of Syrian refugees: security, class and the labour market in Lebanon and Jordan' Mediterranean Politics Vol. 20 (3), 386-404.

Published version available from: http://dx.doi.org/10.1080/13629395.2015.1078125

Accepted version downloaded from SOAS Research Online: http://eprints.soas.ac.uk/23972/

\title{
Cover Page
}

Article Title: Explaining the (non-)encampment of Syrian refugees: security, class and the labour market in Lebanon and Jordan.

Author Name: Lewis Turner

Affiliation: Department of Politics and International Studies, SOAS, University of London

E-Mail Address: lewis_turner@soas.ac.uk

Telephone Number: 00447915929083

Postal Address: Department of Politics and International Studies, SOAS, University of London, Thornhaugh Street, Russell Square, London, United Kingdom, WC1H 0XG.

Funding Information: This article is based on research initially undertaken for an MSc dissertation at SOAS, University of London, and was supported by a Standard Chartered Scholarship.

Disclosure Statement: I have no financial interest or benefit arising from the direct applications of my research. 
This is the accepted version of Turner, Lewis (2015) 'Explaining the (non-)encampment of Syrian refugees: security, class and the labour market in Lebanon and Jordan' Mediterranean Politics Vol. 20 (3), 386-404.

Published version available from: http://dx.doi.org/10.1080/13629395.2015.1078125

Accepted version downloaded from SOAS Research Online: http://eprints.soas.ac.uk/23972/

\section{Explaining the (non-)encampment of Syrian refugees: security, class}

\section{and the labour market in Lebanon and Jordan.}

\section{Abstract}

In Lebanon and Jordan the (non-)encampment of Syrian refugees is serving states' labour market goals. The Lebanese economy 'requires' large numbers of non-encamped low-wage Syrian workers, but the Jordanian regime assists its Transjordanian support base by restricting poor Syrians' access to the labour market through encampment. While acknowledging the importance of both states' differing historical experiences hosting refugees, and the security and budgetary motivations for policies of (non-)encampment, this article uses a critical political economy analysis of economic and labour market statistics to dislodge the centrality of the security discourses that increasingly inform discussions of refugee populations and the policies directed towards them. It demonstrates that the camp is not only a space of humanitarianism or a fertile ground for armed militancy, but a tool through which states spatially segregate those refugees, of certain socio-economic classes, whom they deem surplus to labour market requirements.

\section{Keywords}

refugee camps, encampment, Syrian refugees, Lebanon, Jordan, labour market 
This is the accepted version of Turner, Lewis (2015) 'Explaining the (non-)encampment of Syrian refugees: security, class and the labour market in Lebanon and Jordan' Mediterranean Politics Vol. 20 (3), 386-404.

Published version available from: http://dx.doi.org/10.1080/13629395.2015.1078125

Accepted version downloaded from SOAS Research Online: http://eprints.soas.ac.uk/23972/ 
This is the accepted version of Turner, Lewis (2015) 'Explaining the (non-)encampment of Syrian refugees: security, class and the labour market in Lebanon and Jordan' Mediterranean Politics Vol. 20 (3), 386-404. Published version available from: http://dx.doi.org/10.1080/13629395.2015.1078125

Accepted version downloaded from SOAS Research Online: http://eprints.soas.ac.uk/23972/

\section{Introduction}

In the four years following the beginning of the Syrian uprising, one of the key differences between Lebanon's and Jordan's responses to the Syrian refugee ${ }^{1}$ crisis has been their encampment policies - their policies on the establishment of refugee camps, who will reside in them, and the restrictions placed on those living in them. Lebanon hosts around 1500 informal tented settlements (UNHCR, 2015a), many of which were formed independently by Syrians, but has consistently opposed the establishment of formal refugee camps run by the United Nations High Commissioner for Refugees (UNHCR). No Syrian is made, by law, to live in an informal tented settlement, and the national government mostly allows Syrians to be employed in the informal labour market (International Labour Organization (ILO), 2014a). In Jordan, although around 80 per cent of Syrians live outside of camps, the government has established several refugee camps - most prominently Zaatari, where over 80,000 refugees live ${ }^{2}$. Due to Jordan's increasingly restrictive policies (Achilli, 2015), most Syrians in these camps have no realistic possibility of leaving them legally, except by returning to Syria, and are separated from Jordan's labour market. These contrasting policies are explained by the complex relationship between security and encampment, Lebanon's and Jordan's differing historical experiences of hosting encamped and non-encamped refugees, and crucial factors that are typically under-explored in discussions of encampment: the labour markets in host states, and the relationship between refugees' socio-economic class and policies of (non-)encampment.

${ }^{1}$ In this article, the term 'refugee' is used not only to refer to those who meet the legal definition of refugee found in the 1951 Convention Relating to the Status of Refugees (hereafter 1951 convention), but also to those who have fled generalized violence.

${ }^{2}$ All population figures for Syrian refugees are from UNHCR's online Inter-Agency

Information Sharing Portal: http://data.unhcr.org/syrianrefugees/regional.php 
This is the accepted version of Turner, Lewis (2015) 'Explaining the (non-)encampment of Syrian refugees: security, class and the labour market in Lebanon and Jordan' Mediterranean Politics Vol. 20 (3), 386-404. Published version available from: http://dx.doi.org/10.1080/13629395.2015.1078125

Accepted version downloaded from SOAS Research Online: http://eprints.soas.ac.uk/23972/

It is customarily argued that the perception that refugees are a security threat will increase the likelihood of their spatial segregation in camps and worse treatment by the host state (Jacobsen, 1996; Kibreab, 2007; Loescher and Milner, 2005). However, it is simultaneously recognized that refugee camps can provide armed militants with territory, resources, and recruits, and camps themselves may therefore be deemed a security threat (Terry, 2002). In Lebanon, in which the long-standing Palestinian camps represent extraterritorial sites of radicalization and armed resistance (Hanafi and Long, 2010), fears over the potential militarization of camps, the radicalization of Syrian refugees, and the potential permanence of their presence, have led to a rejection of formal camps. In Jordan, by contrast, the decision to build refugee camps for Syrians was neither prompted by, nor deterred by, security considerations. Palestinian camps in Jordan are now successfully managed by the regime, but the non-encampment of Iraqi refugees disrupted Jordan's attempts to use their presence to raise financial aid (Peteet, 2011; Seeley, 2010). Jordan has strategically used encampment to raise the profile of, and funds for, Syrian refugees on its territory.

The academic and humanitarian literatures on encampment, and the literature specifically focused on Syrian refugees, fail to analyse the ways in which labour market concerns may motivate state policies of (non-)encampment. This article will argue, however, that a full understanding of Lebanon's and Jordan's encampment policies requires an analysis of the labour markets in both countries, the class composition of refugee populations, and the differential effects of encampment policies on refugees of different socio-economic classes. In Lebanon, which has long-relied on the presence of a large, low-wage Syrian labour force (Chalcraft, 2009), non-encampment has restored the level of Syrian 
This is the accepted version of Turner, Lewis (2015) 'Explaining the (non-)encampment of Syrian refugees: security, class and the labour market in Lebanon and Jordan' Mediterranean Politics Vol. 20 (3), 386-404. Published version available from: http://dx.doi.org/10.1080/13629395.2015.1078125

Accepted version downloaded from SOAS Research Online: http://eprints.soas.ac.uk/23972/

participation in the labour market to levels similar to before 2005, when many Syrian workers left Lebanon following the withdrawal of the Syrian Army (ibid). In Jordan, which has been attempting to reduce its reliance on low-wage foreign labour (Chatelard, 2010), over 100,000 mostly lower-class Syrians are excluded from the labour market through encampment. Whereas Lebanon's approach serves the interests of owners of capital, Jordan's policy primarily serves the regime's Transjordanian ${ }^{3}$ supporters, who typically live in rural areas that, with higher unemployment levels pre-dating 2011, have struggled to cope with the influx of Syrian refugees (Ministry of Labour, 2010; Ryan, 2011).

In contrast to the increasing securitization of humanitarian, academic, and political discourses on refugees and refugee camps (Beehner, 2015; Leenders, 2009), this article utilizes a critical political economy approach to demonstrate that refugee workers are just as significant a determinant of state policy towards refugees as the 'refugee warriors' on which so much of the literature focuses (ibid). Where a host state's interests align sufficiently with those of the economic elite, non-encampment enables refugee populations to increase the labour supply, increase worker precarity, and reduce wages. Conversely, where the host state perceives the need to appease or support those who may be negatively affected by a labour supply increase, encampment is a policy that enables states to reduce labour market competition. In the analysis presented here, the camp appears not only as a space of humanitarianism or a fertile ground for armed militancy, but is re-cast as an instantiation of state economic policy, a tool through which

\footnotetext{
3 The term 'Transjordanian,' or 'East Banker', denotes those Jordanian citizens not of Palestinian origin.
} 
This is the accepted version of Turner, Lewis (2015) 'Explaining the (non-)encampment of Syrian refugees: security, class and the labour market in Lebanon and Jordan' Mediterranean Politics Vol. 20 (3), 386-404. Published version available from: http://dx.doi.org/10.1080/13629395.2015.1078125

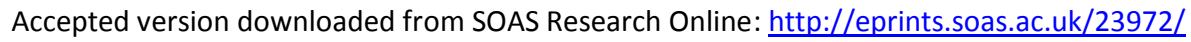

states spatially segregate refugees of certain socio-economic classes, those deemed surplus to labour market requirements.

This article draws on labour market statistics produced by the International Labour Organization (ILO), the Agency for Technical Cooperation and Development (ACTED), the World Bank (WB), the International Rescue Committee (IRC), and the United Nations' Food and Agriculture Organization (FAO), and UNHCR statistics on the Syrian refugee populations in both countries. Since the beginning of the Syrian crisis, these organizations have conducted household labour survey interviews with around 900 households in Lebanon (approximately 700 Syrian and 200 Lebanese households) and around 3,850 households in Jordan (approximately 1,400 out-of-camp Syrian households, 800 Syrian households in Zaatari, 1,500 Jordanian households, and 150 non-Syrian, nonJordanian households). These are complemented by the use of employment and population statistics from Lebanon's Central Administration of Statistics (CAS), Jordan's Ministry of Labour (MoL), and Jordan's Department of Statistics (DoS). The article also draws on the press releases of government agencies and humanitarian organizations, newspaper reports, and grey literature from a range of NGOs and human rights organizations. It will first address state and humanitarian motivations for the encampment of refugees, before examining Lebanon's and Jordan's historical experiences with (non-)encamped Palestinians and Iraqis and how these divergent histories have influenced their policies towards Syrians. Subsequently, it will explore how states' labour market goals and refugees' socio-economic class have a crucial impact on encampment policies in both states.

\section{Motivations for Refugee Encampment}


This is the accepted version of Turner, Lewis (2015) 'Explaining the (non-)encampment of Syrian refugees: security, class and the labour market in Lebanon and Jordan' Mediterranean Politics Vol. 20 (3), 386-404. Published version available from: http://dx.doi.org/10.1080/13629395.2015.1078125

Accepted version downloaded from SOAS Research Online: http://eprints.soas.ac.uk/23972/

The encampment of refugees has long been a 'cornerstone' of humanitarian and state responses to displacement (Peteet, 2005: 29). For the humanitarian organizations running refugee camps, having refugees spatially contained, separated and isolated improves administrative efficiency and facilitates aid distribution (Verdirame and Harrell-Bond, 2005). Refugee camps can aid efforts to attract donations and funding, by rendering refugees 'visible' and countable, 'proving' their presence to potential donors (HarrellBond, 1998). Demonstrating the agency's strong preference for encampment, UNHCR's December 1997 Policy on Refugees in Urban Areas stated that if refugees of a particular nationality were assisted within camps or rural settlements in a host country, UNHCR would provide these refugees with assistance in urban areas 'only with the agreement of the government and if there are compelling reasons to do so' (UNHCR, 1997: 1). This restrictive and deeply controversial policy was replaced in 2009 by the agency's new Policy on Refugee Protection and Solution in Urban Areas, which pledged that UNHCR would provide protection and assistance to refugees in urban areas regardless of whether or not authorities approved of refugees' residence there. Observers speculated that the 2009 policy may represent 'a long-term paradigm shift' towards a focus on out-of-camp refugees, (Refugee Studies Centre, 2010: 22), or even the beginning of the end of refugee camps (Verdirame and Pobjoy, 2013). In July 2014 the agency went even further, declaring in its Alternative to Camps policy that it would 'avoid the establishment of refugee camps, wherever possible,' and that where camps were necessary, for example during emergencies, they should be 'phased out at the earliest possible stage' (UNHCR, 2014a: 6).

States may promote encampment in an attempt to shift the costs and responsibilities associated with refugees to international actors, primarily UNHCR, which usually funds 
This is the accepted version of Turner, Lewis (2015) 'Explaining the (non-)encampment of Syrian refugees: security, class and the labour market in Lebanon and Jordan' Mediterranean Politics Vol. 20 (3), 386-404. Published version available from: http://dx.doi.org/10.1080/13629395.2015.1078125

Accepted version downloaded from SOAS Research Online: http://eprints.soas.ac.uk/23972/

and runs refugee camps (Seeley, 2013). Camps can be used to hold refugees temporarily, before their proposed eventual repatriation to their country of origin, thereby furthering the political aim of non-integration of refugees (Jaji, 2012). These factors notwithstanding, the perception that refugees pose a security risk is often understood to be a key impetus for a policy of encampment. States can be concerned that refugees may attempt to intervene in the conflict from which they fled, trigger an intervention by the state from which they fled, or create destabilising competition for scarce resources (Loescher and Milner, 2005), and may judge that refugees will be more easily monitored and controlled in camps (Jacobsen, 1996). Because refugee movements disrupt the assumed trinity of state/nation/territory that is fundamental to the ideological underpinnings of the modern state system, refugees may even be "presumed to be agents of insecurity' (Jaji, 2012: 227). Conversely, camps themselves may be deemed a security threat, as they can provide shelter, resources and recruits for so-called 'refugee warriors' (Salehyan, 2007), who have at times used the humanitarian label of camps to further their political and military agendas (Loescher and Milner, 2005). States are typically more likely to believe that refugee camps pose a security threat when they judge that refugees are likely to attempt to intervene in an armed conflict, that the refugees' state of origin may intervene militarily against armed refugee movements, and that the state may lack the capacity to effectively control and monitor camps (Loescher and Milner, 2005; Terry, 2002). Whether states or other political actors deem these possibilities to be likely is strongly influenced by the political and historical context of a host state, as will be demonstrated in the Lebanese and Jordanian cases.

\section{Security and the Non-Encampment of Syrian Refugees in Lebanon}


This is the accepted version of Turner, Lewis (2015) 'Explaining the (non-)encampment of Syrian refugees: security, class and the labour market in Lebanon and Jordan' Mediterranean Politics Vol. 20 (3), 386-404. Published version available from: http://dx.doi.org/10.1080/13629395.2015.1078125

Accepted version downloaded from SOAS Research Online: http://eprints.soas.ac.uk/23972/

UNHCR has registered more than 1.1 million Syrian refugees in Lebanon, although the Lebanese government has always estimated the real figure to be significantly higher (UNHCR, 2013a). For the first three years of the Syrian uprising, Lebanon 'broadly maintained an open-border policy' towards Syrians wishing to enter the country (Amnesty International (AI), 2013: 4), although, in line with its longstanding policy of attempting to reduce the size of the Palestinian population (see Peteet, 2005), Lebanon placed restrictions on Palestinians wishing to enter from Syria (AI, 2013). In 2014, however, Lebanon, a non-signatory of the 1951 convention, became increasingly restrictive in its entry policies towards Syrians. In April it shut eighteen unofficial border crossing points that it had previously tolerated (Nayel, 2014), in October the cabinet decided that Lebanon would henceforth only accept refugees in 'exceptional' or 'urgent' humanitarian cases, and in January 2015 that all Syrians wishing to enter Lebanon must obtain a costly visa that severely limits their access to, and length of stay in, Lebanon (UNHCR, 2015b). While Lebanon has allowed Syrians to set up informal tented settlements, or perhaps to an extent, given the weakness of the Lebanese state (Leenders, 2009), was unable to prevent them from doing so, and allowed UNHCR to establish one transit site with 70 shelter units outside Arsal (UNHCR, 2014b), its adamant refusal to contemplate formal, UNHCR-run refugee camps is striking.

The combination of open borders (until October 2014) and non-encampment won Lebanon significant praise from human rights groups and UNHCR (Frelick, 2013). Lebanon's policy articulated with UNHCR's changing attitude to encampment, with Ninette Kelley, the agency's representative to Lebanon, publicly praising the country as 'a model for dealing with refugees' (quoted in Dettmer, 2013). Even in the face of rapidly rising numbers and a shortage of adequate shelter, when UNHCR recommended moving 
This is the accepted version of Turner, Lewis (2015) 'Explaining the (non-)encampment of Syrian refugees: security, class and the labour market in Lebanon and Jordan' Mediterranean Politics Vol. 20 (3), 386-404. Published version available from: http://dx.doi.org/10.1080/13629395.2015.1078125

Accepted version downloaded from SOAS Research Online: http://eprints.soas.ac.uk/23972/

to more formal camps, the Lebanese government, which would require the agreement of all major political forces in the country for such a policy, resolutely refused (Daily Star, 2014a; UNHCR, 2013a). The government's position is opposed by the Lebanese public: 70 per cent of Lebanese are in favour of UNHCR camps for Syrians, a figure which rises to 80 per cent in northern Lebanon, one of the areas most densely populated with Syrian refugees (Christopherson, 2014). Inter-communal tensions have been fuelled by rising prices, the increasingly sectarian nature of the Syrian conflict, sectarian clashes within Lebanon, the distribution of aid to Syrians in close proximity to poverty-stricken Lebanese communities, and competition for jobs and falling wage rates (ILO, 2014a; International Crisis Group (ICG) 2013; Naufal, 2012; WB, 2013). Although it has been argued that spatial segregation through encampment may reduce such conflicts (Jacobsen, 1996), Lebanon has still refused to formally encamp Syrian refugees.

A key aspect of Lebanese hostility to encampment relates to the permanence of Palestinian refugee camps, and their historic, and to some extent contemporary, extraterritoriality. The 1969 Cairo Accord granted Palestinian camps administrative autonomy and permitted Palestinian factions to launch attacks on Israel from Lebanon (Hanafi and Long, 2010). The Palestine Liberation Organization (PLO) was able to build many independent institutions within Lebanon, and refugee camps, controlled and governed by armed factions, were at the heart of Palestinians' projects of nation-building and armed struggle (ibid). Although the Lebanese Parliament unilaterally abrogated the Cairo Accord in 1987, Palestinian camps effectively remain politically autonomous and Palestinian factions remain armed within the camps (Knudsen, 2009). Many Lebanese continue to view Palestinian camps as 'havens of lawlessness,' and many hold Palestinians responsible for the outbreak of the civil war (Khalili, 2005: 37). 
This is the accepted version of Turner, Lewis (2015) 'Explaining the (non-)encampment of Syrian refugees: security, class and the labour market in Lebanon and Jordan' Mediterranean Politics Vol. 20 (3), 386-404. Published version available from: http://dx.doi.org/10.1080/13629395.2015.1078125

Accepted version downloaded from SOAS Research Online: http://eprints.soas.ac.uk/23972/

Informed by this history, Lebanese allies of the al-Asad regime, primarily Hizballah and the Free Patriotic Movement (FPM), are among those most strongly opposed to encampment. The sectarian nature of Lebanon's political system and the sensitivity of the refugee question mean that their agreement would be needed to establish formal camps (UNHCR, 2013a). Hizballah, which sees its fate as closely tied to the Syrian regime, has openly expressed its concern that formal camps could provide safe havens for Syrian rebels, with its Deputy Secretary-General Sheikh Naim Qassem arguing that 'any camp for Syrians in Lebanon will turn into a military pocket that will be used as a launch pad against Syria and then against Lebanon' (quoted in Daily Star, 2012). The FPM, which has been openly hostile to Syrian refugees (ICG, 2013), has claimed that some of those fleeing Syria are deliberately presenting themselves as poor, but are in reality armed militants who have come to Lebanon to 'create troubles' (Naufal, 2012: 17). While some argue that refugees in camps are easier to monitor and control (Jacobsen, 1996), these parties may fear that the weak Lebanese state lacks the capacity to effectively police formal camps, as in the Palestinian case (see Hanafi and Long, 2010), and may be unable to prevent the establishment of armed militias within them. Al-Asad's allies are concerned that camps would shape, strengthen and radicalize the identity of Syrian refugees in Lebanon, reinforcing existing anti-al-Asad sentiment (ICG, 2012).

Furthermore, many Lebanese political parties are reluctant to repeat the policy of creating officially temporary camps for a large, mostly Sunni Muslim refugee population. They fear that camps for Syrians could similarly become enduring features of the landscape and lead to a permanent Syrian population that would destabilize Lebanon's sectarian 'balance' (ICG, 2013; UNHCR 2013a). 
This is the accepted version of Turner, Lewis (2015) 'Explaining the (non-)encampment of Syrian refugees: security, class and the labour market in Lebanon and Jordan' Mediterranean Politics Vol. 20 (3), 386-404. Published version available from: http://dx.doi.org/10.1080/13629395.2015.1078125

Accepted version downloaded from SOAS Research Online: http://eprints.soas.ac.uk/23972/

The Lebanese case is therefore an example of key political actors viewing the establishment of refugee camps as a security threat, rather than a solution to a security threat, because of the history of Palestinian camps in Lebanon, Lebanon's weak state capacity, and the risk that camps could damage al-Asad's regime and cause instability within Lebanon. The perception that refugees are a security threat has led not to a policy of encampment and worse treatment of refugees, as is posited in much of the literature, but to a policy of non-encampment that has been widely heralded as a more humanitarian alternative to forced encampment. While it is crucial not to underestimate the tremendous challenges faced by refugees in Lebanon, unlike over 100,000 refugees in Jordan, they do not find themselves essentially confined by the government to refugee camps with very harsh conditions, very few labour market opportunities, and severe restrictions on freedom of movement (see UNHCR, 2013a).

\section{(Budget) Security and the Encampment of Syrian Refugees in Jordan}

Jordan, like Lebanon a non-signatory of the 1951 convention, regards Syrian refugees as 'guests', a category with no legal meaning (ILO, 2015). UNHCR has registered over 620,000 Syrian refugees in Jordan, including over 100,000 living in camps, although the true figure is likely to be significantly higher. Jordan initially opposed encampment, but as the numbers of Syrians crossing the border continued to increase rapidly and following negotiations with government and tribal leaders in northern Jordan, the government decided to open Zaatari refugee camp in July 2012 (UNHCR, 2013b; Urban Refugees Debate Forum 2013). Zaatari hosts around 80,000 refugees, and Azraq camp, which opened in April 2014, around 18,000. Syrian refugees who enter through one of the more than 40 unofficial border crossings, as the majority of refugees do, are taken to Zaatari or Azraq (Hall, 2013; UNHCR, 2013b). Additionally, approximately 6,000 are 
This is the accepted version of Turner, Lewis (2015) 'Explaining the (non-)encampment of Syrian refugees: security, class and the labour market in Lebanon and Jordan' Mediterranean Politics Vol. 20 (3), 386-404. Published version available from: http://dx.doi.org/10.1080/13629395.2015.1078125

Accepted version downloaded from SOAS Research Online: http://eprints.soas.ac.uk/23972/

hosted at Emirati Jordan Camp, which is funded and run by the United Arab Emirates. Syrians wishing to leave a camp to enter Jordan can only do so legally through the 'bailout' system, in which a Jordanian citizen agrees to act 'as a guarantor of their whereabouts' (Seeley, 2013; c.f. AI, 2013). Hundreds of thousands of Syrians have been able to use this system successfully, although it has led to the exploitation of refugees, many of whom have, in their desperation to leave the camps, paid 'middlemen' around $\$ 500$ to arrange to be 'bailed out' by Jordanian citizens unknown to them (UNHCR, 2013a). Not only is this amount well beyond the means of many refugees, but since early 2014 Jordan has consistently made bailout papers very hard to obtain (Achilli, 2015).

Reflecting the widespread securitization of migration and Jordan's concerns about the on-going conflict in Syria, Jordan's policies towards Syrian refugees are attentive to those whom it deems a potential threat to its security. It holds Syrian military defectors separately to other Syrians, with over 2,000 living in a special military complex (Jordan Times, 2013), denies entry to Syrian men who cannot prove that they have family in Jordan and to any Syrians lacking identity documents (AI, 2013), and has arrested and expelled Syrians accused of being involved with terrorist organizations in Syria or of attempting to establish 'hostile organizations' in Jordan (Syrian Observer, 2014). Yet the establishment of refugee camps for Syrians in Jordan was not prompted by security concerns as much academic literature would predict, but nor did security concerns act as a strong motivator against the encampment of refugees. Jordan's policy, however, like Lebanon's, is influenced by its particular history of hosting refugees.

Jordan built camps for Palestinian refugees after the conflicts of 1948 and 1967, which were, during the height of the PLO's militarized presence in Jordan after the 1967 war, 
This is the accepted version of Turner, Lewis (2015) 'Explaining the (non-)encampment of Syrian refugees: security, class and the labour market in Lebanon and Jordan' Mediterranean Politics Vol. 20 (3), 386-404. Published version available from: http://dx.doi.org/10.1080/13629395.2015.1078125

Accepted version downloaded from SOAS Research Online: http://eprints.soas.ac.uk/23972/

seen as extra-territorial and a serious source of potential instability, as they still are in Lebanon. But camps in Jordan, which has a stronger and more centralized state than Lebanon, are now 'well surveyed' by the government (Peteet, 2011: 23), which appoints a camp director with a significant role in the running of the camp (Misselwitz and Hanafi, 2009). Following the invasion of Iraq, camps were initially set up to receive refugees, but were dismantled after only a small proportion of the expected number sought refuge abroad in the immediate aftermath of the invasion (Marfleet and Chatty, 2009). When Iraqis did start to arrive in Jordan in much greater numbers in late 2005, the overwhelmingly urban, educated and upper- and middle-class Iraqi population refused any suggestion that they should go to camps and instead headed largely for Jordanian cities (Chatelard, 2010; Peteet, 2011).

Jordanian authorities declared that the Iraqis were 'guests', rather than 'refugees,' and did not request international assistance for Iraqis on its territory in the three years immediately following the invasion of Iraq (Goldenziel, 2013; Human Rights Watch (HRW), 2006). Jordan feared that the narrative of an Iraqi refugee crisis would lead to it hosting another permanent refugee population, and it did not want to offend the wealthy Iraqis from whose presence it benefitted (Goldenziel, 2013; Seeley, 2010). On an international level, there was an 'unsettling, if not incredible' quiet about the fate of displaced Iraqis (Peteet, 2007: 8), with the US and UK reticent to admit, or highlight, that the invasion of Iraq had caused mass displacement (Sassoon, 2009). This quiet began to change in part due to a sharp increase in the numbers of displaced Iraqis, the campaigns of human rights organizations and the end of the 2006 conflict in Lebanon (HRW, 2006; Libal and Harding; 2007). But as numbers rose and attention increased, Jordan also began to raise the profile of displaced Iraqis on its territory in an attempt to use their 
This is the accepted version of Turner, Lewis (2015) 'Explaining the (non-)encampment of Syrian refugees: security, class and the labour market in Lebanon and Jordan' Mediterranean Politics Vol. 20 (3), 386-404. Published version available from: http://dx.doi.org/10.1080/13629395.2015.1078125

Accepted version downloaded from SOAS Research Online: http://eprints.soas.ac.uk/23972/

presence to seek financial aid, one of the external rents on which Jordan has relied since its creation (Beck and Hüser, 2015; Seeley, 2010).

Even though there were fewer than 50,000 Iraqis registered with UNHCR in Jordan in 2007 (UNHCR, 2008), Jordan claimed that it was hosting between 750,000 and 1,000,000 Iraqis, costing it $\$ 1$ bn annually (Peteet, 2007). In response to the controversy over these numbers, Jordan commissioned Fafo, a Norwegian research institute, to undertake a comprehensive survey of the number of Iraqis in Jordan, which estimated a figure of only 161,000 (Fafo, 2007). The Jordanian government delayed the publication of the report to 'reconcile' these figures with telephone company information and its own entry and exit records, despite the weaknesses of such data (ibid), and the final report estimated that there were between 450,000 and 500,000 Iraqis in Jordan (Seeley, 2010). Although these higher figures were disputed by many organizations working in Jordan (Stevens, 2013), Jordan subsequently used the figure of 450,000 in its funding appeals (Chatelard, 2011). The non-encampment of Iraqis worked strongly against Jordan's attempts to secure increased financial aid. As observed by both UNHCR's High Commissioner and scholars, the non-encampment of Iraqis made them less 'visible' to the international community (Goldenziel, 2013; Guterres 2007). Camps can turn refugees into a visible and 'spatially legible population' (Peteet, 2011: 18) and facilitate the counting of refugees, which in turn can facilitate fundraising (Harrell-Bond, 1998).

It is argued here that part of the reason why Jordan built camps for Syrians is that it used encampment strategically to enable it to raise the profile of, and receive funds for, Syrian refugees on its territory, a policy that has had some success. When Jordan decided to open Zaatari it made clear that the running costs of the camp, estimated at $\$ 500,000$ per 
This is the accepted version of Turner, Lewis (2015) 'Explaining the (non-)encampment of Syrian refugees: security, class and the labour market in Lebanon and Jordan' Mediterranean Politics Vol. 20 (3), 386-404. Published version available from: http://dx.doi.org/10.1080/13629395.2015.1078125

Accepted version downloaded from SOAS Research Online: http://eprints.soas.ac.uk/23972/

day, were to be borne by UNHCR (Beehner, 2015; Petra News Agency 2012). The focus of international humanitarian organizations, at least until the summer of 2013, was largely on those refugees who were encamped, with Zaatari in particular becoming very high profile, even though a majority of Syrians in Jordan, and in the region as a whole, were not living in camps (UNHCR, 2013a). While hosting refugees in camps is often more expensive than non-camp alternatives (Seeley, 2013; UNHCR, 2014a), it is nonetheless noteworthy, especially considering that a minority of refugees in Jordan are encamped, that UNHCR's 2014 funding targets called for over 50 per cent more funding for Jordan per capita than Lebanon, as had the Regional Response Plan 4 of December 2012 (UNHCR, 2012, 2014b). Furthermore, while UNHCR's funding appeals have consistently not been met, in both 2013 and 2014 the proportional shortfall in funding for Jordan (even with its higher per capita fundraising targets) was the smallest for any of the refugee-hosting countries neighbouring Syria (UNHCR, 2014c, 2015c).

\section{Encampment, Class and the Labour Market}

While security and budgetary pressures influence Lebanese and Jordanian policies towards refugees, refugees' socio-economic class and their effects on domestic labour markets are crucial factors in determining these states' refugee camp policies, yet very little scholarly attention is dedicated to these questions. Much of the academic debate on the motivations for policies of (non-)encampment fails to even mention the labour market as a potential factor (e.g. Black, 1998; Jaji, 2012; Loescher and Milner, 2005). Other oft-cited research that discusses the impact of refugees on the economies and labour markets of host states, nonetheless fails to analyse the potential links between the labour market and policies of (non-)encampment (e.g. Jacobsen, 1996; Kibreab, 1983; Verdirame and Harrell-Bond, 2005). Kibreab’s (2007) acknowledgement that reducing 
This is the accepted version of Turner, Lewis (2015) 'Explaining the (non-)encampment of Syrian refugees: security, class and the labour market in Lebanon and Jordan' Mediterranean Politics Vol. 20 (3), 386-404. Published version available from: http://dx.doi.org/10.1080/13629395.2015.1078125

Accepted version downloaded from SOAS Research Online: http://eprints.soas.ac.uk/23972/

the competition between refugees and nationals for scarce resources, including employment, is one of seven factors potentially motivating the spatial segregation of refugees, is extremely rare within the literature. The academic and humanitarian literatures on Syrian refugees similarly fail to discuss a possible connection between encampment policies and labour market participation (e.g. AI 2013; Hall; 2013; ICG, 2013; Loveless, 2013; Naufal, 2012; UNHCR, 2013a). Even where it is observed that in Lebanon labour market competition is increased by the absence of camps, nonencampment is attributed to concerns about security and a permanent refugee population (e.g. Christophersen, 2014).

In Jordan, confining Syrian refugees from lower socio-economic classes to camps reduces the potential number of labour market participants who could compete with Jordanian workers and push down wages. While Iraqis in Jordan were overwhelmingly urban, well educated, and members of the upper and middle classes (Chatelard, 2010), and Jordan benefitted significantly from their capital and economic investments (Saif and DeBartolo, 2007), Syrian refugees are on average poorer, more rural in origin, and less educated than the Jordanian population (ILO and Fafo, 2015). Syrians in Jordan are typically willing to work for lower wages and longer hours than their Jordanian counterparts (ILO, 2015; ILO and Fafo, 2015), and, unlike in Lebanon, before the refugee crisis, Syrians did not constitute a major part of the Jordanian labour force, although there are over 300,000 foreign workers in Jordan (Chatelard, 2010). The Jordanian Labour Market Panel Survey of 2010, while likely to underestimate the migrant worker population because it surveyed only traditional households, not collective abodes, estimated that Syrians were less than one per cent of the working age population (Assaad, 2012). 
This is the accepted version of Turner, Lewis (2015) 'Explaining the (non-)encampment of Syrian refugees: security, class and the labour market in Lebanon and Jordan' Mediterranean Politics Vol. 20 (3), 386-404. Published version available from: http://dx.doi.org/10.1080/13629395.2015.1078125

Accepted version downloaded from SOAS Research Online: http://eprints.soas.ac.uk/23972/

Jordan's cabinet took the decision to open Zaatari camp in July 2012, citing increasing numbers and the strain placed on Jordan's resources (Petra News Agency, 2012). While UNHCR officials called for the opening of a camp due to overcrowding at the government's reception facilities (Associated Press, 2012), UNHCR has emphasized that the Jordanian government 'insisted upon the establishment of camps' (UNHCR 2013a, 9). According to its representative to Jordan, Andrew Harper, Jordan's decision was taken after consultation with northern government and 'tribal' leaders, who felt that their communities could not continue to absorb Syrian refugees (see Urban Refugees Debate Forum, 2013). While it is difficult to ascertain the extent to which UNHCR's position influenced Jordan's decision to open refugee camps, the Jordanian government devised the particular form that encampment would take, by severely restricting refugees' freedom of movement and freedom to work, and by creating the 'bailout' system. The 'bailout' system has an important class element, because, although it is becoming more restrictive (Achilli, 2015), it has often enabled those Syrians with sufficient access to capital and connections to leave refugee camps into Jordanian host communities, but has simultaneously effectively consigned to camps the poorest Syrians, who might be expected to exert the strongest downward pressure on wages. 87 per cent of refugees in Zaatari, and 58 per cent of out-of-camp Syrians, are from rural backgrounds, and the residents of Zaatari are less likely to have completed secondary or university education than Syrian refugees living outside camps, who in turn are significantly less educated than the Jordanian population (ILO and Fafo, 2015).

Encampment is one key aspect of Jordan's extensive attempts to prevent, or at least reduce, the employment of Syrians. While the government facilitates the provision of 
This is the accepted version of Turner, Lewis (2015) 'Explaining the (non-)encampment of Syrian refugees: security, class and the labour market in Lebanon and Jordan' Mediterranean Politics Vol. 20 (3), 386-404. Published version available from: http://dx.doi.org/10.1080/13629395.2015.1078125

Accepted version downloaded from SOAS Research Online: http://eprints.soas.ac.uk/23972/

investment permits for wealthy Syrians, it granted fewer than 2,600 work permits to Syrians between March 2011 and September 2013 (Hall, 2013; ILO, 2015). The Ministry of Labour has systematically 'scaled up' its enforcement of labour regulations, for example between March and October 2013 closing down 589 businesses, nearly all of which were owned by Jordanians, specifically for employing Syrians without work permits (ILO, 2014b: 20). Many of the Syrians found to be working without permits are taken by Jordanian authorities to live in Zaatari, and thus cannot return to the Jordanian labour market (Achilli, 2015; AI, 2013). As previously noted, Jordan has a long-standing ban on the entry of Syrian men travelling alone if they cannot prove that they have family residing in Jordan. While such restrictions may be assumed to be related to security concerns, it is noteworthy that Syrian men are also over seven times more likely than women to seek work in Jordan (ILO and Fafo, 2015). Jordan's approach is part of its attempts to revise its 'loose foreign labour policy,' a goal set out in its National Employment Strategy for 2011-2020 (Ministry of Planning and International Cooperation (MoPIC), 2011: 70; c.f. Chatelard, 2010).

These measures have successfully restricted the number of Syrians able to work in Jordan. It is estimated that only 51 per cent of working-age (15 years and above) Syrian men and 7 per cent of women living in Jordanian host communities are economically active, and of them only 43 per cent and 12 per cent respectively are employed (ILO and Fafo, 2015). These figures do not even include the Syrians residing in camps, who cannot access the labour market. The contrasting figures for Lebanon show that 70 per cent of working-age Syrian men and 19 per cent of women are economically active, and 79 per cent and 32 per cent of them respectively are employed (ILO, 2014a). Furthermore, while Jordanians widely believe that Syrians are competing with them in the labour 
This is the accepted version of Turner, Lewis (2015) 'Explaining the (non-)encampment of Syrian refugees: security, class and the labour market in Lebanon and Jordan' Mediterranean Politics Vol. 20 (3), 386-404. Published version available from: http://dx.doi.org/10.1080/13629395.2015.1078125

Accepted version downloaded from SOAS Research Online: http://eprints.soas.ac.uk/23972/

market, and notwithstanding the evidence that Syrian workers may be replacing some Jordanians in sectors such as construction and retail, Syrians who are managing to work in Jordan are mainly working in sectors dominated by migrant workers, and are replacing migrant workers from other countries (ILO, 2014b; ILO and Fafo, 2015). Government figures showed, for example, that the number of Egyptians working in Jordan decreased by over 20 per cent between 2010 and 2013 (DoS, n.d.).

Jordan's encampment and labour market policies particularly benefit the Transjordanian, 'tribal', and Bedouin communities that have traditionally formed important power bases for the regime (Schwedler, 2010). While the Jordanian population of Palestinian origin is mostly concentrated in large cities such as Amman, Irbid and Zarqa, Transjordanians are more concentrated in small towns and rural areas (Ryan, 2011), which 'exhibit much higher rates of unemployment' than Jordanian cities (MoPIC, 2011: 58; c.f. MoL 2010). The economic strain of hosting Syrian refugees also falls heavily on Jordanian host communities in rural areas: while almost 80 per cent of Iraqi households in Jordan lived in Amman (Fafo, 2007), under 30 per cent of Syrians do. Mafraq Governorate, for instance, in which over 60 per cent of the 300,000-strong Jordanian population live in settlements of under 5,000, is now host to 70,000 registered non-camp refugees, although its Governor claims that the real figure may be as high as 200,000 (Albawaba, 2015; DoS, 2012a, 2012b).

Even before the Syrian crisis, there were increasing signs of discontent from the traditional supporters of the Hashemite regime. Transjordanians have typically dominated the public sector, military and security services in Jordan, and have therefore consistently been disproportionately disadvantaged by the programmes of neoliberal 
This is the accepted version of Turner, Lewis (2015) 'Explaining the (non-)encampment of Syrian refugees: security, class and the labour market in Lebanon and Jordan' Mediterranean Politics Vol. 20 (3), 386-404. Published version available from: http://dx.doi.org/10.1080/13629395.2015.1078125

Accepted version downloaded from SOAS Research Online: http://eprints.soas.ac.uk/23972/

economic reforms and privatisations that 'accelerated rapidly' under King Abdullah (Ryan, 2010). While benefitting elite Jordanians of Palestinian origin, who are often also allies of the regime, the reforms were an important factor in the 'aggrieved' Transjordanian nationalist voice that grew louder over the 2000s (ibid). The protests that have taken place in Jordan since the beginning of the Arab uprisings, while diverse, have primarily been initiated and led by Transjordanians motivated by economic grievances, including rising prices and stagnant wages (Beck and Hüser 2015; Ryan, 2011). The years 2011-2013 witnessed an explosion of labour-related protests in Jordan, with an average of over 870 protests per year, compared to 139 in 2010 (Jordan Labour Watch, 2014). Jordan's encampment and labour market policies must be understood within this context of economic grievances and unrest.

While UNHCR and ILO statistics demonstrate that the Syrian populations in Lebanon and Jordan are similar in terms of age, gender, and educational attainment (ILO, 2014a; ILO and Fafo, 2015), Lebanon's contrasting policies also pursue labour market goals. A historically-informed analysis of the Lebanese economy demonstrates that Lebanon's refusal to build formal camps is designed to serve Lebanese owners of businesses and capital by expanding the labour supply, lowering wages, and increasing workers' precarity: the absence of formal camps has both security and economic rationales. Syrian workers have, for decades, formed 'the bulk of [Lebanon's] unskilled workforce' (Chalcraft, 2007: 28). Lebanon's and Syria’s 1993 agreement for Economic and Social Cooperation and Coordination gives Syrians freedom of stay, work, employment and practice of economic activity in Lebanon, and while Syrians are technically required to get work permits in Lebanon, only a tiny proportion do, and the vast majority have always worked in the informal economy. Government statistics for 2013, for example, 
This is the accepted version of Turner, Lewis (2015) 'Explaining the (non-)encampment of Syrian refugees: security, class and the labour market in Lebanon and Jordan' Mediterranean Politics Vol. 20 (3), 386-404. Published version available from: http://dx.doi.org/10.1080/13629395.2015.1078125

Accepted version downloaded from SOAS Research Online: http://eprints.soas.ac.uk/23972/

show that despite a Syrian population of over 1 million, only 1,233 work permits were issued or renewed for Syrian citizens that year (CAS, 2013). While precise figures do not exist, estimates for the early 2000s claimed that Syrians constituted between 20 and 40 per cent of Lebanon's labour force (Chalcraft, 2009), although large numbers left Lebanon following the withdrawal of the Syrian Army in 2005 and the Israeli bombardment of 2006 (ibid; Khalili, 2005). While many subsequently returned, or came from Syria for the first time (Chalcraft, 2007), the World Bank estimates that Syrians were only 17 per cent of the labour force immediately before the Syrian uprising (WB, 2013).

Syrian refugees in Lebanon participate extensively in the Lebanese labour market, particularly in the construction and agricultural sectors (ACTED, 2014). As previously noted, 70 per cent of Syrian working-age men and 19 per cent of working-age Syrian women are participating in the labour market, and 79 per cent of those men, and 32 per cent of those women, are employed (ILO, 2014a; ILO and Fafo, 2015). 92 per cent have no formal work contract, 56 per cent are employed on a seasonal, weekly, or daily basis, and Syrians' average monthly wage is about $\$ 290$, nearly 40 per cent lower than the Lebanese monthly minimum wage of approximately $\$ 450$ (ibid; c.f. IRC, 2013). The increase in a precarious labour supply has reduced overall wage levels for unskilled labour, particularly in the Bekaa Valley, with daily wages in some areas having fallen by as much as 60 per cent since the beginning of the Syrian crisis (FAO, 2013; IRC, 2013). It is widely acknowledged by Syrians and Lebanese alike that Syrians are willing to work for lower wages and longer hours, prompting some Lebanese employees to express their willingness to accept lower wages in order to avoid being replaced by Syrians (ILO, 2014a). 
This is the accepted version of Turner, Lewis (2015) 'Explaining the (non-)encampment of Syrian refugees: security, class and the labour market in Lebanon and Jordan' Mediterranean Politics Vol. 20 (3), 386-404. Published version available from: http://dx.doi.org/10.1080/13629395.2015.1078125

Accepted version downloaded from SOAS Research Online: http://eprints.soas.ac.uk/23972/

The influx of refugees into Lebanon, and the decision not to separate them from the labour market through formal encampment, is restoring previous levels of Syrian participation in the Lebanese economy. In September 2013 the World Bank estimated that in 2014 Syrians 'may constitute between 27 and 35 per cent' of the labour force, similar to the estimated levels in the early 2000s, and up from its 2011 level of 17 per cent (WB, 2013: 84). In the 8 months following the publication of the report, the number of Syrians registered by UNHCR in Lebanon increased by almost 390,000, and given this continued dramatic increase in the size of the Syrian population in Lebanon, it would be reasonable to expect that the World Bank's estimates were realistic. Any policy that attempted to keep a large proportion of Syrians in camps and to restrict their freedom of movement and labour would damage the many sectors of the Lebanese economy that use, or even rely upon, cheap Syrian labour. Lebanese owners of businesses and capital, who have for decades 'actively sought' a menial labour regime for Syrians (Chalcraft, 2009: 224), are the clear economic beneficiaries of the policy of non-encampment.

At least until mid-2014, when Lebanon's attitude to the entry of Syrian refugees became increasingly restrictive, it consistently showed leniency towards those who did not obtain a work permit, and informal labour market participation has been very high, as has been detailed (ILO, 2014a). Nonetheless, as restrictions on their entry to Lebanon increased, there have been some police campaigns targeting Syrians refugees in employment (AlAkhbar, 2015). However, it is noteworthy that, unlike Jordan, which since the beginning of the crisis has consistently attempted to prevent Syrians from working in the labour market, the sporadic targeting of Syrian workers in Lebanon has occurred concurrently to its increasingly restrictive border policies. Both may reflect the fact that while Lebanon 
This is the accepted version of Turner, Lewis (2015) 'Explaining the (non-)encampment of Syrian refugees: security, class and the labour market in Lebanon and Jordan' Mediterranean Politics Vol. 20 (3), 386-404.

Published version available from: http://dx.doi.org/10.1080/13629395.2015.1078125

Accepted version downloaded from SOAS Research Online: http://eprints.soas.ac.uk/23972/

has allowed previous levels of Syrian participation in the economy to be restored, and is benefitting from this policy, it does not want an on-going unlimited increase in the Syrian labour supply, particularly considering the social strains that the Syrian crisis has placed on Lebanon. Furthermore, many police actions towards Syrians have targeted businesses set up and owned by Syrians, which have undercut their Lebanese counterparts by selling items produced in Syria (Daily Star, 2014b; ILO, 2014a).

The centrality of the labour market is reinforced when one examines the situation of Syrians in informal tented settlements. In many cases, in order to rent a space for their tent, Syrians must work for the landowner in construction or agriculture (Nayel, 2014), meaning these settlements are also regularly a means for the exploitation of a precarious labour force. While over 40 Lebanese municipalities have imposed evening and nighttime curfews on Syrians (HRW, 2015), these restrictions on movement do not interfere with their ability to participate in the labour market. Some have claimed that the informal tented settlements across the country represent a de facto system of encampment (Loveless, 2013). However, even if one were to accept this characterization of the Lebanese context, it is crucial to note that, as in Jordan, the particular form of encampment is tailored to suit the state's interests, in Lebanon's case its 'need' for a cheap and docile Syrian labour force. Syrians in Lebanon, regardless of when they entered the country, could now simultaneously be thought of as refugees and members of the informal labour force.

\section{Conclusion}

By drawing critically on economic and labour statistics compiled by governments and transnational organizations, this article disrupts the securitization of refugees and refugee 
This is the accepted version of Turner, Lewis (2015) 'Explaining the (non-)encampment of Syrian refugees: security, class and the labour market in Lebanon and Jordan' Mediterranean Politics Vol. 20 (3), 386-404. Published version available from: http://dx.doi.org/10.1080/13629395.2015.1078125

Accepted version downloaded from SOAS Research Online: http://eprints.soas.ac.uk/23972/

camps, and demonstrates the importance of the labour market, refugees' socio-economic class, and economic policy-making to states' decisions about encampment and the treatment of refugees. While this argument has drawn on the specific cases of Lebanon and Jordan, it also illuminates the mechanisms through which states manage their labour markets and discipline their domestic labour forces in other contexts of large-scale forced migration. Where a host state believes its interests align sufficiently with an economic elite, is committed to a de-regulated labour market, and content to be reliant on large migrant worker populations, refugees of a low socio-economic class become an economic resource to be harnessed. Non-encampment and the facilitation of labour market participation are methods through which states create the necessary circumstances for the exploitation of the labour force (see LeBaron, 2015). These policies lead to an increased labour supply, deflationary pressure on wages, and a nonnational labour force is thereby used to increase the economic precarity of nationals and non-nationals alike (see Standing, 2011). Conversely, in other contexts, refugees can be understood to represent an economic threat in need of containment. Large-scale migration is regularly (perceived to) create labour market competition with nationals and to worsen the economic situation in a host country (Heizmann, 2015). Where this (perception of) labour market competition leads to popular discontent and political pressure from sectors of the population that are considered in a position to threaten a regime's power, that regime may encamp refugees, thereby prioritizing its stability over the potential economic gains that could be accumulated through the exploitation of a precarious labour force.

Academic research has demonstrated that refugee camps, as sites of humanitarian care and control (Agier, 2011), facilitate the distribution of aid and improve administrative 
This is the accepted version of Turner, Lewis (2015) 'Explaining the (non-)encampment of Syrian refugees: security, class and the labour market in Lebanon and Jordan' Mediterranean Politics Vol. 20 (3), 386-404. Published version available from: http://dx.doi.org/10.1080/13629395.2015.1078125

Accepted version downloaded from SOAS Research Online: http://eprints.soas.ac.uk/23972/

efficiency for humanitarian agencies (Verdirame and Harrell-Bond, 2005). Camps can be a device for the monitoring and containment of refugees (Jacobsen, 1996), a site of radicalization and armed militancy (Terry, 2002), and a response to state security concerns (Loescher and Milner, 2005). However, to view states' responses to refugee influxes solely through prevailing lenses of security or humanitarianism obscures the multiplicity of goals that states seek to achieve through their refugee camp policies. Just as scholars have argued that the categories of 'forced' and 'voluntary', or 'political' and 'economic,' migration do not capture the complexity of migrants' experiences (Adamson, 2006; Chatelard, 2010; Chatty and Marfleet, 2013), it must be recognized that refugees fleeing violence and persecution are simultaneously potential members of the labour force in their host states. The research presented here has demonstrated that the refugee camp, with its humanitarian veneer, is a particularly draconian tool through which states attempt to regulate the size and class composition of their domestic labour markets in response to refugee influxes. The recognition that states refuse to contemplate, or insist on building, refugee camps in order to integrate different classes of refugees into, or separate them from, the domestic economy, is crucial for developing a comprehensive understanding of for which groups of refugees camps are built, who is confined to them, and what conditions and restrictions they must suffer. 
This is the accepted version of Turner, Lewis (2015) 'Explaining the (non-)encampment of Syrian refugees: security, class and the labour market in Lebanon and Jordan' Mediterranean Politics Vol. 20 (3), 386-404.

Published version available from: http://dx.doi.org/10.1080/13629395.2015.1078125

Accepted version downloaded from SOAS Research Online: http://eprints.soas.ac.uk/23972/

Acknowledgements: The author would like to thank Rachel Diamond, Pamela G.

Faber, Jessy Nassar, Mathew Shearman, Mathilde Zederman and three anonymous reviewers for their comments on previous drafts, and Laleh Khalili, for her invaluable guidance and encouragement. 
This is the accepted version of Turner, Lewis (2015) 'Explaining the (non-)encampment of Syrian refugees: security, class and the labour market in Lebanon and Jordan' Mediterranean Politics Vol. 20 (3), 386-404.

Published version available from: http://dx.doi.org/10.1080/13629395.2015.1078125

Accepted version downloaded from SOAS Research Online: http://eprints.soas.ac.uk/23972/

\section{References}

Achilli, L. (2015) Syrian Refugees in Jordan: A Reality Check, Migration Policy Centre, available at: http://cadmus.eui.eu/bitstream/handle/1814/34904/MPC_2015-

02_PB.pdf?sequence $=1$ (accessed: 3 March 2015)

ACTED (2014) Labour Market Assessment in Beirut and Mount Lebanon (Beirut: ACTED).

Adamson, F. (2006) International Migration and National Security, International Security, 31(1), pp. 165-199.

Agier, M. (2011) Managing the Undesirables: Refugee Camps and Humanitarian Government.

(Cambridge, UK; Malden: Polity).

AI (2013) Growing Restrictions, Tough Conditions: The Plight of Those Fleeing Syria to Jordan.

(London: AI) (October).

Al-Akhbar (2015) Raids on businesses employing Syrians further threaten refugees in

Lebanon, Al-Akhbar, 5 January, available at: http://english.al-akhbar.com/node/23101 (accessed 4 May 2015).

Albawaba (2015) Syrians make up 88\% of Jordan's Mafraq population, Albawaba, 1

March, available at: http://www.albawaba.com/news/syrians-make-88-

jordan\%E2\%80\%99s-mafraq-population-663034 (accessed 17 March 2015). 
This is the accepted version of Turner, Lewis (2015) 'Explaining the (non-)encampment of Syrian refugees: security, class and the labour market in Lebanon and Jordan' Mediterranean Politics Vol. 20 (3), 386-404. Published version available from: http://dx.doi.org/10.1080/13629395.2015.1078125

Accepted version downloaded from SOAS Research Online: http://eprints.soas.ac.uk/23972/

Assaad, R. (2012) The Structure and Evolution of Employment in Jordan, Economic Research Forum Working Paper No. 674 (Cairo: ERF).

Associated Press (2012) UN urges Jordan to open camps for Syrian refugees, Associated Press, 3 July, available at: http://bigstory.ap.org/article/un-urges-jordan-open-campsyrian-refugees (accessed: 21 March 2015).

Beck, M. and Hüser, S. (2015) Jordan and the 'Arab Spring': No challenge, no change? Middle East Critique, 24(1), pp. 83-97.

Beehner, L. (2015) Are Syria’s do-it-yourself refugees outliers or examples of a new norm?, Journal of International Affairs, 68(2), pp. 157-175.

Black, R. (1998) Putting refugees in camps, Forced Migration Review, 2, pp. 4-7.

CAS (2013) Statistical Yearbook Time Series 2011-2013, available at http://www.cas.gov.lb/index.php/statistical-yearbook (accessed 23 March 2015).

Chalcraft, J. (2007) Labour in the Levant, New Left Review, 45, pp. 27-47.

Chalcraft, J. (2009) The Invisible Cage: Syrian Migrant Workers in Lebanon (Stanford; London: Stanford University Press).

Chatelard, G. (2010) Jordan: a refugee haven. Migration Policy Institute, 31 August, available at: http://www.migrationpolicy.org/print/4357\#.U8U9qahblXs (accessed 7 June 2014). 
This is the accepted version of Turner, Lewis (2015) 'Explaining the (non-)encampment of Syrian refugees: security, class and the labour market in Lebanon and Jordan' Mediterranean Politics Vol. 20 (3), 386-404. Published version available from: http://dx.doi.org/10.1080/13629395.2015.1078125

Accepted version downloaded from SOAS Research Online: http://eprints.soas.ac.uk/23972/

Chatelard, G. (2011) Iraqi refugees and IDPs, Middle East Institute, 9 June, available at: http://www.refugeecooperation.org/publications/iraq/pdf/09_chatelard.pdf (accessed 30 May 2014).

Chatty, D. and Marfleet, P. (2013) Conceptual Problems in Forced Migration, Refugee Survey Quarterly, 32(2), pp. 1-13.

Christophersen, M. (2014) Absence of Syrian refugee camps in Lebanon heats up labor competition and local tensions, International Peace Institute, 17 March. Available at: http://reliefweb.int/report/lebanon/absence-syrian-refugee-camps-lebanon-heats-laborcompetition-and-local-tensions (accessed 24 March 2014).

Daily Star (2012) Hezbollah rejects Syrian refugee camps in Lebanon, Daily Star, 10 March, available at: http://www.dailystar.com.lb/News/Lebanon-News/2012/Mar10/166204-hezbollah-rejects-syrian-refugee-camps-in-lebanon.ashx\#axzz33f1dpl5Z (accessed: 24 March 2014).

Daily Star (2014a) Formal camps the only way to solve refugee crisis: Abu Faour, Daily Star, 13 May, available at: http://www.dailystar.com.lb/News/LebanonNews/2014/May-13/256224-formal-camps-the-only-way-to-solve-refugee-crisis-abufaour.ashx (accessed: 5 June 2014).

Daily Star (2014b) Crackdown shutters Syrians businesses in Bekaa Valley, Daily Star, 24 July, available at: http://www.dailystar.com.lb/News/Lebanon-News/2014/Jul- 
This is the accepted version of Turner, Lewis (2015) 'Explaining the (non-)encampment of Syrian refugees: security, class and the labour market in Lebanon and Jordan' Mediterranean Politics Vol. 20 (3), 386-404. Published version available from: http://dx.doi.org/10.1080/13629395.2015.1078125

Accepted version downloaded from SOAS Research Online: http://eprints.soas.ac.uk/23972/

24/264917-crackdown-shutters-syrian-businesses-in-bekaa-valley.ashx (accessed 5 May 2015).

DoS (2012a) Estimated Population of the Kingdom by Urban and Rural, at End-year 2012, available at: http://www.dos.gov.jo/dos_home_a/main/2004/2012/2-3.pdf (accessed: 14 March 2015).

DoS (2012b) Estimated Population of the Kingdom, Area, and Population Density by Governorate, at End-year 2012, http://www.dos.gov.jo/dos_home_a/main/2004/2012/2-6.pdf (accessed: 14 March 2015).

DoS (n.d.) Employees by Economic Activity, Nationality and Sex, available at: http://www.dos.gov.jo/dos_home_e/main/linked-html/employment/index.htm (accessed: 20 March 2015).

Dettmer, J. (2013) It's about time: United Nations plans refugee camps for Syrians in Lebanon, The Daily Beast, 6 December, available at: http://www.thedailybeast.com/articles/2013/06/12/it-s-about-time-united-nationsplans-refugee-camps-for-syrians-in-lebanon.html (accessed 5 July 2014).

Fafo (2007) Iraqis in Jordan 2007: Their Number and Characteristics (Oslo: Fafo).

FAO (2013) Agricultural Livelihoods and Food Security Impact Assessment and Response Plan for the Syria Crisis in the Neighbouring Countries of Egypt, Iraq, Jordan, Lebanon and Turkey (Rome: FAO). 
This is the accepted version of Turner, Lewis (2015) 'Explaining the (non-)encampment of Syrian refugees: security, class and the labour market in Lebanon and Jordan' Mediterranean Politics Vol. 20 (3), 386-404. Published version available from: http://dx.doi.org/10.1080/13629395.2015.1078125

Accepted version downloaded from SOAS Research Online: http://eprints.soas.ac.uk/23972/

Frelick, B. (2013) Fleeing Syria: insights on Lebanon's open border, Human Rights Watch, 24 March, available at: http://www.hrw.org/news/2013/03/24/fleeing-syria-insightslebanon-s-open-border (accessed 25 March 2014).

Goldenziel, J.I. (2013) Regulating human rights: International organizations, flexible standards, and international refugee law, Chicago Journal of International Law, 14(2), pp. 453492.

Guterres, A. (2007) Statement by Mr. Antonio Guterres to the Conference on Addressing the Humanitarian Needs of Refugees and Internally Displaced Persons inside Iraq and in Neighbouring Countries, Geneva, UNHCR, 17 April, available at: http://www.unhcr.org/462490411.html (accessed 25 July 2014).

Hall, M. (2013) The Syrian crisis in Jordan, Middle East Report Online, 24 June, available at: http://www.merip.org/mero/mero062413 (accessed 3 August 2014).

Hanafi, S. and T. Long (2010) Governance, governmentalities, and the state of exception in the Palestinian refugee camps in Lebanon, Journal of Refugee Studies, 23(2), pp. 134-159.

Harrell-Bond, B. (1998) Camps: literature review, Forced Migration Review, 2, pp. 22-23.

Heizmann, B. (2015) Social policy and perceived immigrant labour market competition in Europe: is prevention better than cure? Social Forces, 93(4), pp. 1655-1685. 
This is the accepted version of Turner, Lewis (2015) 'Explaining the (non-)encampment of Syrian refugees: security, class and the labour market in Lebanon and Jordan' Mediterranean Politics Vol. 20 (3), 386-404. Published version available from: http://dx.doi.org/10.1080/13629395.2015.1078125

Accepted version downloaded from SOAS Research Online: http://eprints.soas.ac.uk/23972/

HRW (2006) The Silent Treatment: Fleeing Iraq, Surviving in Jordan (New York: HRW)

(November).

HRW (2015) World Report 2015: Events of 2014 (New York: HRW).

ICG (2012) A Precarious Balancing Act: Lebanon and the Syrian Conflict (Beirut; Brussels: ICG) (22 November).

ICG (2013) Too Close for Comfort: Syrians in Lebanon (Beirut; Brussels: ICG) (13 May).

ILO (2014a) Assessment of the Impact of Syrian Refugees in Lebanon and their Employment Profile (Beirut: ILO).

ILO (2014b) The Impact of the Syrian Refugee Crisis on the Labour Market in Jordan: A Preliminary Analysis (Beirut: ILO).

ILO (2015) Access to Work for Syrian Refugees in Jordan: A Discussion Paper on Labour and Refugee Laws and Policies (Beirut: ILO).

ILO and Fafo (2015) Impact of Syrian Refugees on the Jordanian Labour Market (Beirut: ILO).

IRC (2013) Emergency Market Mapping Analysis of the Agricultural Labour Market System in North and Bekaa, Lebanon (Beirut: IRC). 
This is the accepted version of Turner, Lewis (2015) 'Explaining the (non-)encampment of Syrian refugees: security, class and the labour market in Lebanon and Jordan' Mediterranean Politics Vol. 20 (3), 386-404. Published version available from: http://dx.doi.org/10.1080/13629395.2015.1078125

Accepted version downloaded from SOAS Research Online: http://eprints.soas.ac.uk/23972/

Jacobsen, K. (1996) Factors influencing the policy responses of host governments to mass refugee influxes, International Migration Review, 30(3), pp. 655-678.

Jaji, R. (2012) Social technology and refugee encampment in Kenya, Journal of Refugee Studies, 25(2), pp. 221-238.

Jordan Labour Watch (2014) Labour Protests in Jordan 2013 (Amman: Phenix Centre for Economic and Informatics Studies) (April).

Jordan Times (2013) Jordan hosts 2,130 Syrian army defectors - Majali, Jordan Times (Amman), 15 September, available at: http://jordantimes.com/jordan-hosts-2130-syrianarmy-defectors----majali (accessed 4 August 2014).

Khalili, L. (2005) A landscape of uncertainty: Palestinians in Lebanon, Middle East Report, 236, pp. 34-39.

Kibreab, G. (1983) Reflections on the African Refugee Problem: Critical Analysis of Some Basic Assumptions (Uppsala: Scandinavian Institute of African Studies).

Kibreab, G. (2007) Why governments prefer spatially segregated settlement sites for urban refugees, Refuge, 24(1), pp. 27-35.

Knudsen, A. (2009) Widening the protection gap: the 'politics of citizenship' for Palestinian refugees in Lebanon, 1948-2008, Journal of Refugee Studies, 22(1), pp. 51-73. 
This is the accepted version of Turner, Lewis (2015) 'Explaining the (non-)encampment of Syrian refugees: security, class and the labour market in Lebanon and Jordan' Mediterranean Politics Vol. 20 (3), 386-404. Published version available from: http://dx.doi.org/10.1080/13629395.2015.1078125

Accepted version downloaded from SOAS Research Online: http://eprints.soas.ac.uk/23972/

LeBaron, G. (2015) Unfree labour beyond binaries, International Feminist Journal of Politics, 17(1), pp. 1-19.

Leenders, R. (2009) Refugee warriors or war refugees? Iraqi refugees' predicament in Syria, Jordan and Lebanon, Mediterranean Politics, 14(3), pp. 343-363.

Libal, K. and S. Harding (2007) The politics of refugee advocacy and humanitarian assistance, Middle East Report, 244, pp. 18-21.

Loescher, G. and J. Milner (2005) Protracted Refugee Situations: Domestic and International Security Implications (Abingdon: Routledge).

Loveless, J. (2013) Crisis in Lebanon: camps for Syrian refugees? Forced Migration Review, 43, pp. 66-68.

Marfleet, P. and Chatty, D. (2009) Iraq's Refugees: Beyond 'Tolerance' (Oxford: Refugee Studies Centre) (December).

Misselwitz, P. and S. Hanafi (2009) Testing a new paradigm: UNRWA's camp improvement programme, Refugee Survey Quarterly, 28(2-3), pp. 360-388.

MoL (2010) Suq al-'amal al-urduni bi-alarqam 2010 [The Labour Market in Figures 2010] (Amman: Ministry of Labour). 
This is the accepted version of Turner, Lewis (2015) 'Explaining the (non-)encampment of Syrian refugees: security, class and the labour market in Lebanon and Jordan' Mediterranean Politics Vol. 20 (3), 386-404. Published version available from: http://dx.doi.org/10.1080/13629395.2015.1078125

Accepted version downloaded from SOAS Research Online: http://eprints.soas.ac.uk/23972/

MoPIC (2011) Jordan's National Employment Strategy, available at:

http://www.ilo.org/beirut/countries/jordan/lang--en/index.htm (accessed: 7 February 2015).

Naufal, H. (2012) Syrian Refugees in Lebanon: The Humanitarian Approach under Political Division (Florence: Migration Policy Centre).

Nayel, M.A. (2014) On the struggle of Syrian refugees in Lebanon, Jadaliyya, 17 April, available at: http://www.jadaliyya.com/pages/index/17306/on-the-struggle-of-syrianrefugees-in-lebanon. (accessed 22 April 2014).

Peteet, J. (2005) Landscape of Hope and Despair: Palestinian Refugee Camps (Philadelphia; Bristol: University of Pennsylvania Press).

Peteet, J. (2007) Unsettling the categories of displacement, Middle East Report, 244, pp. 2-9.

Peteet, J. (2011) Cartographic violence, displacement and refugee camps: Palestine and Iraq, in A. Knudsen and S. Hanafi (Eds) Palestinian Refugees: Identity, Space and Place in the Levant (Abingdon: Routledge).

Petra News Agency (2012) Jordan to set up Syrian refugee camps, Petra News Agency, 9 July, available at: http://petra.gov.jo/Public_News/Nws_NewsDetails.aspx?lang=2\&site_id=1\&NewsID $=77363$ (accessed: 3 June 2014). 
This is the accepted version of Turner, Lewis (2015) 'Explaining the (non-)encampment of Syrian refugees: security, class and the labour market in Lebanon and Jordan' Mediterranean Politics Vol. 20 (3), 386-404.

Published version available from: http://dx.doi.org/10.1080/13629395.2015.1078125

Accepted version downloaded from SOAS Research Online: http://eprints.soas.ac.uk/23972/

Refugee Studies Centre (RSC) (2010) Forced Migration Research and Policy: Overview of Current

Trends and Future Directions (Oxford: RSC).

Ryan, C. (2010) 'We are all Jordan'...but who is we?, Middle East Report Online, 13 July, available at: http://www.merip.org/mero/mero071310 (accessed 8 April 2014).

Ryan, C. (2011) Identity politics, reform, and protest in Jordan, Studies in Ethnicity and Nationalism, 11(3), pp. 564-578.

Saif, I. and D. DeBartolo (2007) The Iraq war's impact on growth and inflation in Jordan, Centre for Strategic Studies, University of Jordan, available at:

http://www.carim.org/public/polsoctexts/PS2JOR028_EN.pdf (accessed 25 July 2014).

Salehyan, I. (2007) Transnational rebels: neighboring states as sanctuary for rebel groups, World Politics, 59(2), pp. 217-242.

Sassoon, J. (2009) The Iraqi Refugees: The New Crisis in the Middle East (London; New York: I.B. Tauris.)

Schwedler, J. (2010) Jordan's risky business as usual, Middle East Report Online, 30 June, available at: http://merip.org/mero/mero063010 (accessed 8 April 2014).

Seeley, N. (2010) The politics of aid to Iraqi refugees in Jordan, Middle East Report 256, pp. $37-42$. 
This is the accepted version of Turner, Lewis (2015) 'Explaining the (non-)encampment of Syrian refugees: security, class and the labour market in Lebanon and Jordan' Mediterranean Politics Vol. 20 (3), 386-404. Published version available from: http://dx.doi.org/10.1080/13629395.2015.1078125

Accepted version downloaded from SOAS Research Online: http://eprints.soas.ac.uk/23972/

Seeley, N. (2013) The last refugee camp, Foreign Policy, 30 October, available at:

http://www.foreignpolicy.com/articles/2013/10/30/the_last_refugee_camp (accessed 17 July 2014).

Standing, G. (2011) The Precariat: The New Dangerous Class (London: Bloomsbury Academic).

Stevens, D. (2013) Legal status, labelling, and protection: The case of Iraqi 'refugees' in Jordan, International Journal of Refugee Law, 25(1), pp. 1-38.

Syrian Observer (2014) Jordan expels Syrian refugees involved with terrorist organizations, Syrian Observer, 1 December, available at: http://syrianobserver.com/News/News/Jordan+Expels+Syrian+Refugees+Involved + with+Terrorist+Organizations (accessed 6 December 2014).

Terry, F. (2002) Condemned to Repeat?: The Paradox of Humanitarian Action (Ithaca: Cornell University Press).

UNHCR (1997) UNHCR Policy on Refugees in Urban Areas (Geneva: UNHCR).

UNHCR (2008) Statistical Yearbook 2007: Trends in Displacement, Protection and Solution (Geneva: UNHCR).

UNHCR (2012) Syria Regional Response Plan: January to June 2013 (Geneva: UNHCR) (December). 
This is the accepted version of Turner, Lewis (2015) 'Explaining the (non-)encampment of Syrian refugees: security, class and the labour market in Lebanon and Jordan' Mediterranean Politics Vol. 20 (3), 386-404. Published version available from: http://dx.doi.org/10.1080/13629395.2015.1078125

Accepted version downloaded from SOAS Research Online: http://eprints.soas.ac.uk/23972/

UNHCR (2013a) From Slow Boil to Breaking Point: A Real-Time Evaluation of UNHCR's

Response to the Syrian Refugee Emergency (Geneva: UNHCR) (July).

UNHCR (2013b) Syrian Refugees Living Outside Camps in Jordan (Amman: UNHCR).

UNHCR (2014a) UNHCR Policy on Alternatives to Camps (Geneva: UNHCR).

UNHCR (2014b) 2014 Syrian Regional Response Plan Strategic Overview Mid-Year Update (Geneva: UNHCR)

UNHCR (2014c) Syria Regional Response Plan 5: Funding Status as of End of December 2013

(Geneva: UNHCR).

UNHCR (2015a) Lebanon Informal Settlements Locations (Beirut: UNHCR) (29 January)

UNHCR (2015b) Syrian Refugees in Lebanon: Quarterly Snapshot January - March 2015 (Beirut: UNHCR).

UNHCR (2015c) 2014 Syria Regional Response Plan 6: Funding Snapshot (Geneva: UNHCR)

(5 February).

Urban Refugees Debate Forum (2013) A rejoinder, Urban Refugees Debate Forum, 28

August, available at: http://urban-refugees.org/debate/rejoinder/ (accessed 12 February 2015). 
This is the accepted version of Turner, Lewis (2015) 'Explaining the (non-)encampment of Syrian refugees: security, class and the labour market in Lebanon and Jordan' Mediterranean Politics Vol. 20 (3), 386-404. Published version available from: http://dx.doi.org/10.1080/13629395.2015.1078125

Accepted version downloaded from SOAS Research Online: http://eprints.soas.ac.uk/23972/

Verdirame, G. and B. Harrell-Bond (2005) Rights in Exile: Janus-Faced Humanitarianism (New York; Oxford: Berghahn).

Verdirame, G. and J. Pobjoy (2013) The end of refugee camps? In Juss, S. (Ed) The Ashgate Research Companion to Migration Law, Theory and Policy (Farnham: Ashgate).

WB (2013) Lebanon - economic and social impact assessment of the Syrian conflict (Washington, DC: WB) (20 September). 